\title{
2013 Fellows of the American Dairy Science Association
}

The 2013 elected fellows were recognized at the Awards Program of the American Dairy Science Association held on July 10, 2013, at the Hyatt Regency Indianapolis, Indiana. Election to Fellow is one of the highest honors that the Association bestows. The Fellow Award recognizes ADSA members for their distinguished service to the dairy industry for 20 years or more. Each nominee must have made exceptional contributions to the dairy industry, to a dairy-related discipline, or to ADSA; must have had professional membership in ADSA for a minimum of 20 years; and must be in good standing with the Association.

\section{David K. Beede}

David K. Beede has been a member of and leader within ADSA since 1974. He is a dedicated and visionary leader who has had his "finger on the pulse" of the dairy

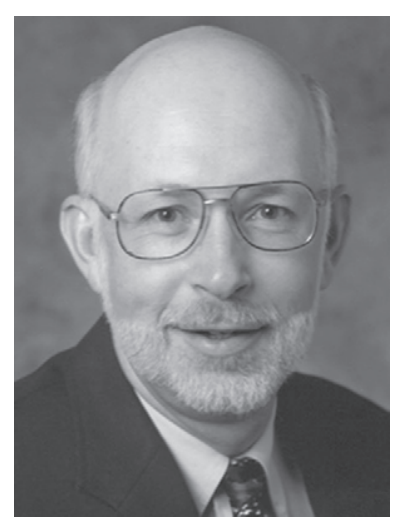
industry, allowing changes to be made proactively. He has the foresight to identify future challenges and his leadership has greatly benefited ADSA as well as the dairy industry.

Dr. Beede's record of service to ADSA is very strong and extensive including, a two-term membership on the Editorial Board of the Journal of Dairy Science (JDS) in the late 1980s and extensive leadership for ADSA annual meetings. He was Chair of the 1988-1989 ADSA Physiology Program Committee, ADSA Production Division Secretary and Chair in 1996-1997, Chair of the ASDA Production Division Meeting Program in 1997, and Overall Chair of the Joint Meeting Program Planning Committee in 2000 in Baltimore. Dr. Beede became more deeply involved in the leadership of ADSA when he was elected to the Board of Directors on which he served from 1998-2004. He was elected Vice President in 2001, and served as President from 2002-2003 and immediate Past President from 2003-2004. In addition, he served on the Federation of Animal Science Societies (FASS) Board of Directors from 2003-2004.

Dr. Beede has contributed to the dairy industry through research, graduate student training, extension/ outreach, and by serving as a member of the National Academy of Sciences National Research Council Subcommittee on Dairy Cattle Nutrition from 1997 to 2001. His research has focused on animal well-being including heat stress and transition cow management (exercise for dry cows and calcium metabolism to reduce milk fever) and the environment including air quality and reducing phosphorus supplementation. Dr. Beede has received several national and state awards recognizing the quality and impact of his research and extension work. In addition, Dr. Beede is an excellent mentor of graduate students, several of whom have won awards.

As a faculty member, currently at Michigan State University (1994-present) and previously at the University of Florida (1980-1994), Dr. Beede has researched issues that are of the utmost importance to the dairy industry related to animal nutrition, management, and the environment. Furthermore, he has provided important leadership for the dairy industry in Michigan, Florida, and the United States. As the Meadows Endowed Chair Professor of Dairy Management, Dr. Beede has provided outstanding leadership for the MSU Dairy Team including establishing and acting as managing publisher of the Michigan Dairy Review, a highly regarded publication resulting from Dr. Beede's vision, initiative, and leadership to the dairy industry in Michigan and the United States.

Dr. Beede's contributions to ADSA and the dairy industry have been outstanding, and he has provided passionate and visionary service to ADSA consistently for well over thirty years. His leadership strategically helped shape the Association to be responsive to change so it can continue to benefit its members, dairy science, and society well into the future. For a career of service to the dairy industry and to ADSA in particular, we are pleased to make David K. Beede a Fellow of the American Dairy Science Association.

\section{Robert J. Collier}

Bob Collier is nationally and internationally recognized for his research and publications in the areas of the biology of lactation and environmental physiology over a 42-year period from 1971 to 2013 . While on the faculty at the University of Florida, he demonstrated that heat stress during late pregnancy significantly 
reduced milk yield in the subsequent lactation. He then demonstrated that there was a seasonal trend in birth weight of dairy calves that was related to the seasonal trend in milk yield. He subsequently demonstrated that summer heat stress altered placental function leading to lower birth weights as well as reduced mammarygland development. These results were later confirmed by other research groups in several different locations in the world and have led to altered management of dairy cows during late pregnancy worldwide to reduce environmental heat load and thus improve calf birth weight and milk yields of the dam during lactation. This reduction in birth weight of calves was also related to lowered resistance of calves to disease because of failure of immunoglobulin transfer. Collier was the first to publish the hormonal requirements for initiation of milk secretion in the dairy cow while a graduate student at the University of Illinois and then went on to author or coauthor more than 70 papers on the biology of growth hormone and prolactin regulation of milk secretion during lactation in the dairy cow. He also copublished a series of papers on the role of bovine placental lactogen, a hormone produced by the fetal placenta on mammary development and milk synthesis in the dairy cow. Since 1999 Collier has been a professor in the Department of Animal Science at the University of Arizona. Since coming to Tucson he has published a series of papers revising the temperature-humidity index, which is used to determine cooling needs for dairy cows during summer months. He has also published extensively on the effect of environmental heat stress on gene expression in the dairy cow and has identified molecular pathways associated with resistance to heat stress. Collier and his then student, Laura Hernandez, also collaborated with Nelson Horseman of the University of Cincinnati to identify a new regulatory system in the mammary gland that is driven by the neurotransmitter, serotonin. This has opened a whole new area of research into the role of this molecule in regulation of mammary-gland function. His group has identified 5 different receptors for this molecule in the mammary gland of the cow, and there are several potential roles for this molecule. To date it has been demonstrated that serotonin is involved in regulation of milk synthesis, mammary blood flow, and calcium mobilization in the lactating dairy cow. Finally, Collier published a series of papers on nutritional management of dairy cows during hot weather and has collaborated with several investigators over the years to devise methods for improved nutritional management of the heat-stressed dairy cow. Collier was recently named by Western Dairy Magazine as educator or scientist of the year for 2013. Collier also previously received the Upjohn Physiology Award, The Land O'Lakes Award for Dairy Research, and the University of Illinois Alumni Award of Merit. In addition, he was awarded an Honorary Research Fellow from the Hannah Research Institute (University of Glasgow, Scotland). He has authored or coauthored 366 journal articles, chapters in books, reviews, and abstracts as well as 9 US patents and 53 popular articles.

For a career of service to the dairy industry and to ADSA in particular, we are pleased to make Robert J. Collier a Fellow of the American Dairy Science Association.

\section{F. Xavier Malcata}

F. Xavier Malcata's academic journey began in 1987 when he applied for a doctoral program at the University of Wisconsin-Madison, at the interface of food science

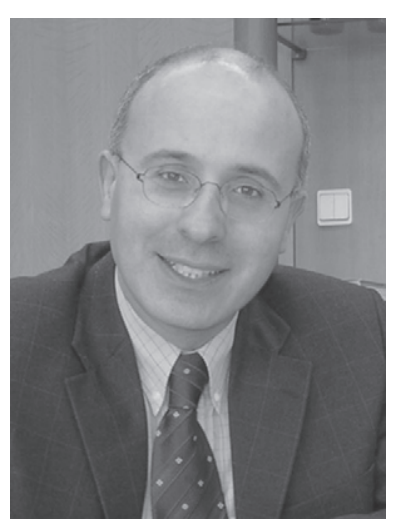
and chemical engineering. He started his graduate studies the following year under the supervision of Charles G. Hill Jr. and the late Clyde Amundson, with a focus on reactors for lipase-mediated transformation of butter oil; his pioneering efforts in this field soon became apparent. After earning his $\mathrm{PhD}$ degree in 1991, he has been able to consistently maintain a remarkable combination of

applied research, administrative prowess, and service to the Portuguese, European, and international dairy industries.

At present, Malcata is full professor at the College of Engineering of the University of Porto, where he is responsible for training in food engineering; he has previously served as dean of the College of Biotechnology of the Portuguese Catholic University for 11 consecutive years. Malcata has a keen intellect, a prodigious work capacity, remarkable professional ethics, and the ability to motivate others and create consensus around innovative ideas; he has been uniquely successful in transmitting and making those innovative ideas work in practice, while contributing for education and $R \& D$ of students in dairy fields. 
The outstanding program of basic and applied research, outreach to industry, initial and advanced professional training, and support to entrepreneurship in Portugal launched by Malcata has become a milestone in Portugal and abroad. Besides several award-winning training materials and programs launched under his coordination, the analytical and processing facilities operated under his supervision have been instrumental toward technology transfer and high-quality support to the dairy industry. One of the best examples of his outstanding ability to design and organize projects that eventually lead to major effects was the establishment of a Technological Pole for the Food Industry in Portugal (INTEGRALAR). This was inspired by the French and Finnish models of technological public policies but adapted to Portuguese conditions. The major goals were to promote differentiation, efficiency, and competitiveness of the food sector, and especially of subsectors with the largest market potential (as is the case of dairy).

The service rendered by Malcata to the dairy industry has also grown out of application of his distinguished record of basic and applied research. Major research interests have encompassed technological improvement of traditional dairy foods and development of nutraceutical ingredients and functional dairy foods; these have led to several patents, besides ca. 600 technical presentations worldwide and more than 400 refereed international publications in respected journals (including the Journal of Dairy Science). It is noteworthy that he ranks among the top international researchers in agricultural sciences even though most of his work has been carried out in Portugal, a country known for modest development indicators within the member states of the EU.

Malcata's integrated efforts in research, education, and industrial extension have been internationally recognized by several prestigious awards, such as the Ralph Potts Memorial Award and the Young Scientist Research Award (AOCS), the Canadian \& International Constituency Investigator Award in Physical Sciences and Engineering (Sigma Xi), the Samuel Cate Prescott Award (IFT), the Scientist of the Year Award (EFFoST), the Elmer Marth Educator Award and the International Leadership Award (IAFP), and the Foundation Scholar Award-Dairy Foods Division, the Danisco International Dairy Science Award, and the Distinguished Service Award (ADSA), besides the French Decoration as Chevalier dans l'Ordre des Palmes Académiques. He has also been previously elected as Fellow of IFT and Fellow of IAFoST. The work acknowledged by the aforementioned awards covers well the area of dairy science and technology; the corresponding public statements have emphasized the innovative and impressive modes of application of science and engineering concepts to food items at large and dairy products in particular, in view of their direct or indirect application to large-scale processes and commercial products.

The international stature of Malcata's achievements in and service to the dairy sector are also apparent via his choice for membership in one of the most active scientific panels of the European Food Safety Authority (the European equivalent of the FDA in the United States). He has also represented the Portuguese government at the European Commission, in the areas of Food Quality and Safety and Agriculture, within the Knowledge-Based Bio-Economy Program of the VI and VII Framework Programs of Research and Development. However, the important roles played by and the growing success of his former alumni in academe, industry, and public administration are probably a better metric of his exemplary service and unusual commitment to the dairy field via high-quality training and advanced education.

For a career of service to the dairy industry and to ADSA in particular, we are pleased to make F. Xavier Malcata a Fellow of the American Dairy Science Association.

\section{Dale Van Vleck}

L. Dale Van Vleck's contributions to science, in a long and productive career, began with publication of 20 papers in the year he was granted a PhD from Cor-

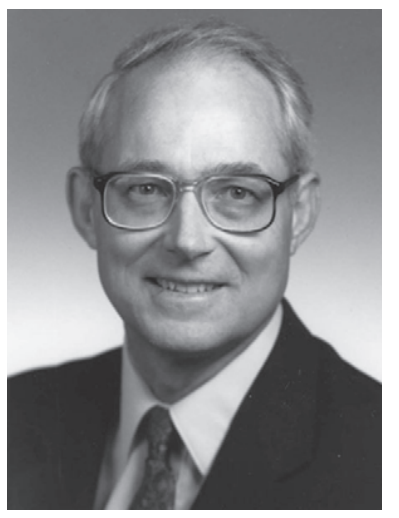
nell University (1960). Since then, he has been author or coauthor of almost 380 peerreviewed scientific papers, 275 abstracts, 14 books, 11 chapters in books, 111 contributions to proceedings of numerous conferences, and 120 articles for farm and extension publications. Most of his papers have been published in the Journal of Dairy Science and Journal of Animal Science. Although his first and second careers were focused in depth on dairy and beef cattle genetics, the breadth of his interests is shown by publications involving sheep, swine, chickens, goats, horses, dogs, corn, and water buffalo. His originality and creativity have been reflected repeatedly on a widely diverse number of topics. He has been a pioneer in developing innovative quantitative and computational approaches devoted to the goal of genetic improvement. Van 
Vleck's main goal has been to provide ways to increase net genetic value. Use of in-progress milk yields and test-day models by him and his colleagues provide for most efficient use of records for genetic improvement. Similarly, evaluations with the animal model using techniques developed by his group have affected genetic improvement in the major livestock species, beef and dairy cattle, sheep, and swine, in many countries. The across-breed adjustment factors for beef cattle together with within-breed animal model evaluations allow all commercial beef producers the opportunity to select from sires of as many as 16 breeds to maximize income for their situation.

Van Vleck has received many awards in his distinguished career, including the American Society of Animal Science's highest award, the Morrison Award. In addition, he has been given a Pioneer Award by both The Beef Improvement Federation and The National Dairy Shrine, an unusual accomplishment and a first for a USDA research scientist.

Van Vleck has chaired supervisory committees of 49 $\mathrm{PhD}$ and $29 \mathrm{MS}$ graduate committees and has been a member of 87 other committees, which may be more in animal breeding and genetics than anyone since Jay L. Lush. In addition, he has hosted 67 visiting scientists from the United States and many other countries. Of special importance has been his work with 14 postdoctoral students and research associates; many now hold important and prestigious positions at universities and research institutions worldwide.

Since retirement, Van Vleck has continued to be active. He has coauthored four peer-reviewed papers, with more in the pipeline, and coauthored six abstracts and four reports for the beef industry, has mentored three visiting scientists, and has advised ARS-USDA researchers as well as researchers at several commercial companies and universities (especially graduate students).

For a career of service to the dairy industry and to ADSA in particular, we are pleased to make L. Dale Van Vleck a Fellow of the American Dairy Science Association. 